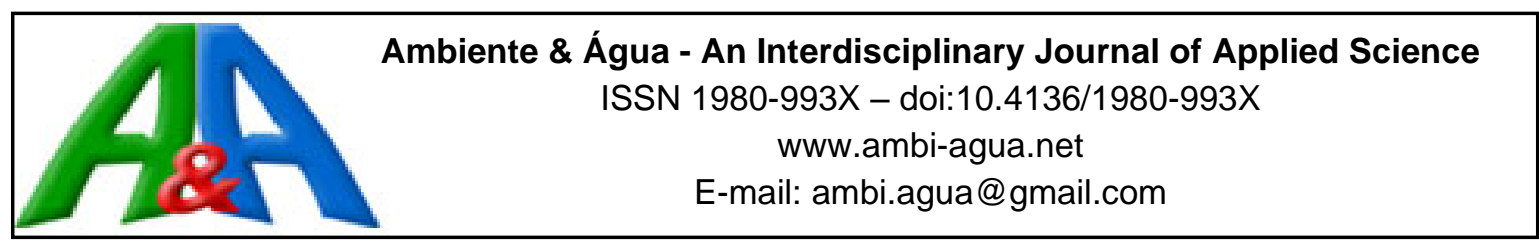

\title{
Nitrite build-up effect on nitrous oxide emissions in a laboratory-scale anaerobic/aerobic/anoxic/aerobic sequencing batch reactor
}

\author{
ARTICLES doi:10.4136/ambi-agua.2634
}

Received: 16 Jun. 2020; Accepted: 20 Jan. 2021

\section{Larissa Coelho Auto Gomes ${ }^{1 *}$; Barbara Costa Pereira ${ }^{1}$; Renato Pereira Ribeiro ${ }^{2}$; Jaime Lopes da Mota Oliveira ${ }^{1}$}

\author{
${ }^{1}$ Departamento de Saneamento e Saúde Ambiental (DSSA). Escola Nacional de Saúde Pública Sérgio Arouca \\ (ENSP/Fiocruz), Rua Leopoldo Bulhões, n 1480, CEP: 21041-210, Rio de Janeiro, RJ, Brazil. \\ E-mail: barbaracp90@gmail.com,jaimel@ensp.fiocruz.br \\ ${ }^{2}$ Centro Experimental de Monitoramento e Mitigação Ambiental. Instituto Federal do Rio de Janeiro (IFRJ), Rua \\ Lúcio Tavares, n 1045, CEP: 26530-060, Nilópolis, RJ, Brazil. E-mail: renato.ribeiro@ifrj.edu.br \\ *Corresponding author. E-mail: larissa.coelho.auto@gmail.com
}

\begin{abstract}
Biological wastewater treatment processes with biological nitrogen removal are potential sources of nitrous oxide $\left(\mathrm{N}_{2} \mathrm{O}\right)$ emissions. It is important to expand knowledge on the controlling factors associated with $\mathrm{N}_{2} \mathrm{O}$ production, in order to propose emission mitigation strategies. This study therefore sought to identify the parameters that favor nitrite $\left(\mathrm{NO}_{2}{ }^{-}\right)$ accumulation and its influence on $\mathrm{N}_{2} \mathrm{O}$ production and emission in an anaerobic/aerobic/anoxic/aerobic sequencing batch reactor with biological nitrogen removal. Even with controlled dissolved oxygen concentrations and oxidation reduction potential, the first aerobic phase promoted only partial nitrification, resulting in $\mathrm{NO}_{2}{ }^{-}$build-up (ranging from 29 to 57\%) and consequent $\mathrm{N}_{2} \mathrm{O}$ generation. The $\mathrm{NO}_{2}{ }^{-}$was not fully consumed in the subsequent anoxic phase, leading to even greater $\mathrm{N}_{2} \mathrm{O}$ production through partial denitrification. A direct relationship was observed between $\mathrm{NO}_{2}{ }^{-}$accumulation in these phases and $\mathrm{N}_{2} \mathrm{O}$ production. In the first aerobic phase, the $\mathrm{N}_{2} \mathrm{O} / \mathrm{NO}_{2}{ }^{-}$ratio varied between 0.5 to $8.5 \%$, while in the anoxic one values ranged between 8.3 and $22.7 \%$. Higher $\mathrm{N}_{2} \mathrm{O}$ production was therefore noted during the anoxic phase compared to the first aerobic phase. As a result, the highest $\mathrm{N}_{2} \mathrm{O}$ fluxes occurred in the second aerobic phase, ranging from 706 to $2416 \mathrm{mg} \mathrm{N} \mathrm{m}^{-2} \mathrm{~h}^{-1}$, as soon as aeration was triggered. Complete nitrification and denitrification promotion in this system was proven to be the key factor to avoid $\mathrm{NO}_{2}^{-}$build-up and, consequently, $\mathrm{N}_{2} \mathrm{O}$ emissions.
\end{abstract}

Keywords: nitrite accumulation, nitrous oxide production and emission, sequencing batch reactor.

\section{Efeito do acúmulo de nitrito na emissão de óxido nitroso de um reator em batelada sequencial anaeróbio/aeróbio/anóxico/aeróbio em escala de laboratório}

\section{RESUMO}

Os processos de tratamento biológico de esgotos com remoção biológica de nitrogênio são potenciais fontes de emissão de óxido nitroso $\left(\mathrm{N}_{2} \mathrm{O}\right)$. No entanto, é importante ampliar o conhecimento dos principais fatores de controle associados à produção de $\mathrm{N}_{2} \mathrm{O}$ para propor estratégias de mitigação de sua emissão. O objetivo deste estudo foi identificar os parâmetros 
que favoreceram o acúmulo de nitrito $\left(\mathrm{NO}_{2}{ }^{-}\right)$e sua influência na produção e emissão de $\mathrm{N}_{2} \mathrm{O}$ em um reator em batelada sequencial anaeróbio/aeróbio/anóxico/aeróbio com remoção de nitrogênio. Mesmo com a concentração de oxigênio dissolvido e o potencial redox controlados, a primeira fase aeróbia promoveu apenas a nitrificação parcial resultando em acúmulo de $\mathrm{NO}_{2}{ }^{-}$ (variando de 29 a 57\%) e geração de $\mathrm{N}_{2} \mathrm{O}$. Este $\mathrm{NO}_{2}{ }^{-}$não foi totalmente consumido na fase anóxica subsequente promovendo uma produção ainda maior de $\mathrm{N}_{2} \mathrm{O}$ pela desnitrificação parcial. Foi observada uma relação direta entre o acúmulo de $\mathrm{NO}_{2}{ }^{-}$nessas fases e a produção de $\mathrm{N}_{2} \mathrm{O}$. Enquanto na primeira fase aeróbia a razão $\mathrm{N}_{2} \mathrm{O} / \mathrm{NO}_{2}{ }^{-}$variou entre 0,5 a $8,5 \%$, na anóxica foi entre 8,3 e $22,7 \%$. Portanto, houve uma maior produção de $\mathrm{N}_{2} \mathrm{O}$ durante a fase anóxica do que na primeira fase aeróbia. Com isso, os maiores fluxos de $\mathrm{N}_{2} \mathrm{O}$ ocorreram na segunda fase aeróbia, variando de 706 a $2416 \mathrm{mg} \mathrm{N} \mathrm{m}^{-2} \mathrm{~h}^{-1}$, assim que a aeração foi acionada. A promoção da nitrificação e da desnitrificação completas neste sistema mostrou ser o fator chave para evitar o acúmulo de $\mathrm{NO}_{2}{ }^{-}$e, consequentemente, a emissão de $\mathrm{N}_{2} \mathrm{O}$.

Palavras-chave: acúmulo de nitrito, produção e emissão de óxido nitroso, reator em batelada sequencial.

\section{INTRODUCTION}

High nitrogen $(\mathrm{N})$ concentrations in effluents may cause eutrophication and deterioration of recipient water bodies. $\mathrm{N}$ overloads favor microalgae and water plant growth, which may release toxins into the water (von Sperling, 2005). Although non-toxic, geosmin and 2methylisoborneol (2-MIB), two products released by cyanobacteria, can influence drinking water organoleptic characteristics, representing an obstacle to water treatment (Freitas et al., 2008). In order to prevent eutrophication, wastewater treatment plants (WWTPs) must be improved to ensure that $\mathrm{N}$ loads to receiving water bodies are within the limits stipulated by local legislation (Yang et al., 2017).

An economically viable and widely studied alternative for $\mathrm{N}$ removal is the application of biological processes involving nitrification and denitrification (von Sperling, 2005). However, the possibility of $\mathrm{N}_{2} \mathrm{O}$ release exists in both reactions, thus resulting in an anthropogenic source of this gas into the atmosphere (Wrage et al., 2001). In the troposphere, $\mathrm{N}_{2} \mathrm{O}$ is a chemically stable and long-lived greenhouse gas, with a global warming potential about 265 times that of carbon dioxide $\left(\mathrm{CO}_{2}\right)$ (IPCC, 2014). Furthermore, in the stratosphere, $\mathrm{N}_{2} \mathrm{O}$ is the most emitted gas from anthropogenic sources displaying ozone $\left(\mathrm{O}_{3}\right)$ depletion potential (Ravishankara et al., 2009). The highest $\mathrm{N}_{2} \mathrm{O}$ emission rates in WWTPs occur on those that apply biological processes, especially those that operate nitrification and denitrification processes in activated sludge (IPCC, 2019).

During nitrification under aerobic conditions, the ammonium ion $\left(\mathrm{NH}_{4}{ }^{+}\right)$is converted to hydroxylamine $\left(\mathrm{NH}_{2} \mathrm{OH}\right)$, which is, in turn, oxidized to nitrite $\left(\mathrm{NO}_{2}^{-}\right)$with the participation of ammonia-oxidizing bacteria (AOB) under alkaline conditions, while $\mathrm{NO}_{2}{ }^{-}$is oxidized to nitrate $\left(\mathrm{NO}_{3}{ }^{-}\right)$by nitrite-oxidizing bacteria (NOB). During denitrification under anoxic conditions, facultative heterotrophic bacteria convert $\mathrm{NO}_{3}{ }^{-}$into molecular $\mathrm{N}\left(\mathrm{N}_{2}\right)$ (Wrage et al., 2001). $\mathrm{N}_{2} \mathrm{O}$ production is commonly attributed to three pathways: (1) partial nitrification, as a by-product of $\mathrm{NH}_{2} \mathrm{OH}$ oxidation; (2) nitrifier denitrification, which can occur under oxygen-limiting conditions, as an intermediate product; and (3) heterotrophic denitrification, where $\mathrm{N}_{2} \mathrm{O}$ is an intermediate product but can be released when the process is incomplete (Duan et al., 2017; Terada et al., 2017). Variations in $\mathrm{N}_{2} \mathrm{O}$ production and emissions occur according to the type of applied treatment process and configuration and operational parameters (Law et al., 2012).

$\mathrm{N}_{2} \mathrm{O}$ generation is usually associated with dissolved oxygen (DO) concentrations, $\mathrm{NH}_{4}{ }^{+}$ and $\mathrm{NO}_{2}^{-}$accumulation, $\mathrm{pH}$ and organic carbon availability (Duan et al., 2017; Vasilaki et al., 
2019). Pijuan et al. (2014) reported $\mathrm{N}_{2} \mathrm{O}$ emissions almost ten-fold higher when altering a pilot plant system from continuous operation to a sequencing batch reactor (SBR). The authors attributed the $\mathrm{N}_{2} \mathrm{O}$ increases to the transient conditions between the anoxic and aerobic stages. Rodriguez-Caballero et al. (2015) also reported higher emissions in a full-scale SBR due to anoxic/aerobic transition. The authors also pointed out $\mathrm{NO}_{2}^{-}$build-up and the length of the aeration phases as contributors. Thus, SBR may become a potential source of emissions when applying operational conditions that favor $\mathrm{N}_{2} \mathrm{O}$ generation.

Knowledge of parameters that affect $\mathrm{N}_{2} \mathrm{O}$ production during the nitrification and denitrification stages is necessary to improve the sustainability of the process (Blum et al. 2018). Therefore, this study evaluated and identified the parameters responsible for $\mathrm{NO}_{2}^{-}$buildup and its effects on $\mathrm{N}_{2} \mathrm{O}$ production and emission in an SBR operated under anaerobic/aerobic/anoxic/aerobic conditions.

\section{MATERIAL AND METHODS}

\subsection{SBR operation}

The study was carried out in a laboratory-scale anaerobic/aerobic/anoxic/aerobic SBR (Figure 1A). The different SBR system phases were adjusted and regulated by a programmable logic controller (PLC), favoring higher DO and oxidation reduction potential (ORP) control. The reactor comprises $8.1 \mathrm{~L}$ of working volume and treats $4 \mathrm{~L}$ during each 8 -hour cycle (Figure 1B). An air compressor pump was used to provide system aeration, with an air flow rate of $120 \mathrm{~L} \mathrm{~h}^{-1}$. Peristaltic pumps were used for the feeding and discharge of raw and treated wastewater, respectively. A mixed liquor volume was removed from the reactor during each cycle by a peristaltic pump, to guarantee a solid retention time (SRT) of 30 days.
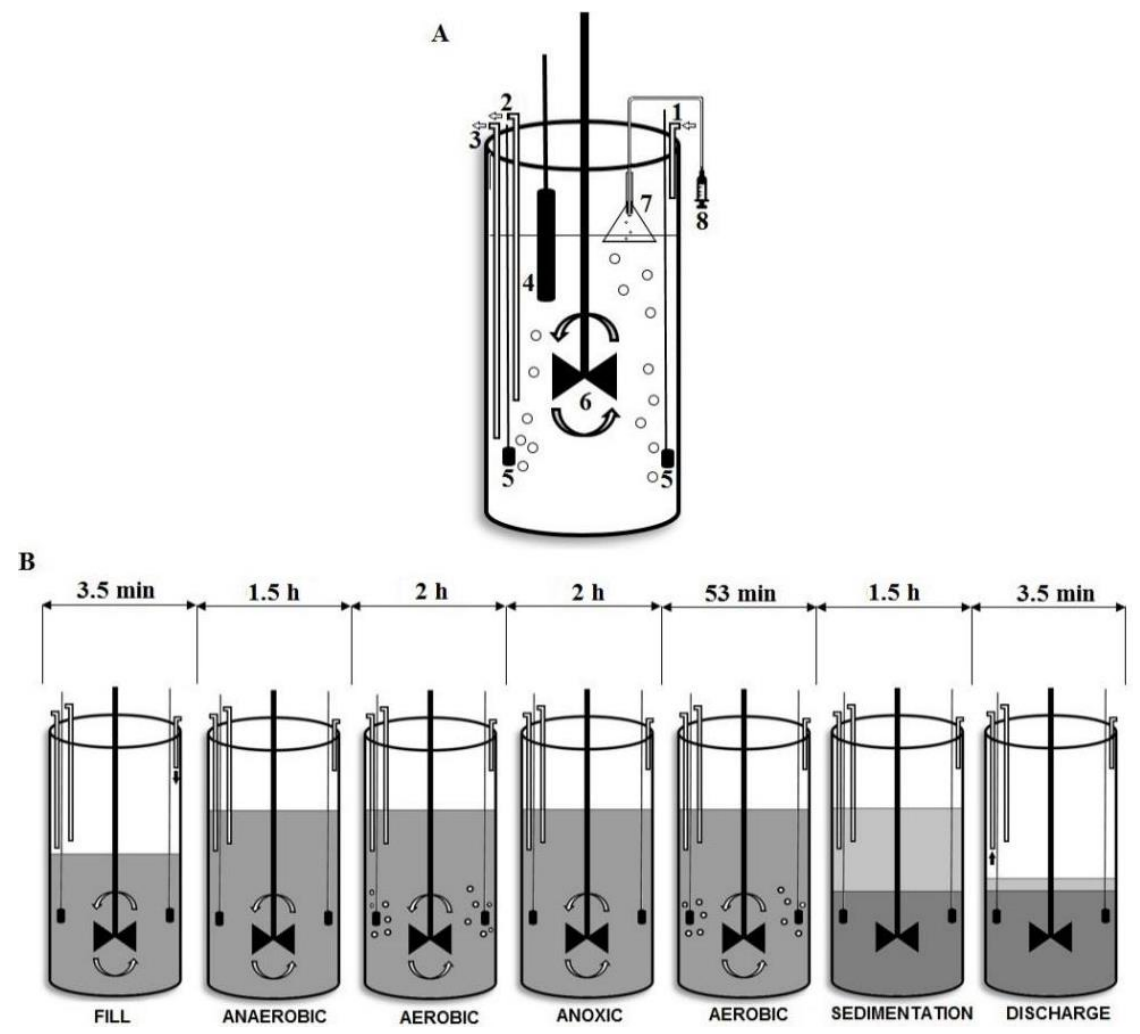

Figure 1. (A) SBR schematic: 1 - wastewater inlet; 2 - mixed liquor outlet; 3 - treated wastewater outlet; $4-\mathrm{DO}, \mathrm{pH}$ and ORP probe; 5 oxygen diffuser; 6 - mechanical agitator; 7 - inverted funnel; 8 - syringe.

(B) SBR cycle schematic. 
The reactor was inoculated with sludge from a WWTP designed to treat sanitary wastewater from a 2,500 population equivalent (PE) and fed with synthetic wastewater, which was prepared by adapting the formulation used by Holler and Trösh (2001). The synthetic wastewater was composed of casein peptone $\left(500 \mathrm{mg} \mathrm{N} \mathrm{L}^{-1}\right)$, beef extract $\left(323 \mathrm{mg} \mathrm{N} \mathrm{L}^{-1}\right)$, dibasic potassium phosphate $\left(35 \mathrm{mg} \mathrm{N} \mathrm{L}^{-1}\right)$, sodium chloride $\left(24 \mathrm{mg} \mathrm{N} \mathrm{L}^{-1}\right)$, urea $\left(23 \mathrm{mg} \mathrm{N} \mathrm{L}^{-}\right.$ $\left.{ }^{1}\right)$, calcium chloride dihydrate $\left(23 \mathrm{mg} \mathrm{N} \mathrm{L}^{-1}\right)$ and magnesium sulfate heptahydrate $\left(11 \mathrm{mg} \mathrm{N} \mathrm{L}^{-}\right.$

$\left.{ }^{1}\right)$. SBR stabilization took 2 months. After this period, samples were collected for efficiency and $\mathrm{N}_{2} \mathrm{O}$ production and emission assessments.

\subsection{Sampling and analysis}

Monitoring took place for six consecutive weeks, where one sampling of one cycle was performed (one cycle per week). Throughout the sampling stage, raw and treated wastewaters were collected for chemical oxygen demand (COD), dissolved organic carbon (DOC) and total nitrogen (TN) analyses. In addition, volatile suspended solids (VSS) were analyzed in the discharged mixed liquor. After each metabolic phase, mixed liquor samples were collected for $\mathrm{NO}_{2}{ }^{-}$and $\mathrm{NO}_{3}{ }^{-}$analysis. Dissolved and emitted $\mathrm{N}_{2} \mathrm{O}$ sampling were also carried out during this period.

COD and VSS were determined according to APHA et al. (2012). DOC and TN analyses were performed on a TOC-L and TN Analyzer model TOC-L/TNM-L (Shimadzu). $\mathrm{NO}_{2}{ }^{-}$and $\mathrm{NO}_{3}{ }^{-}$analyses were performed by a Personal IC ion chromatograph (Metrohm) with conductivity detector, using a Polyvinyl alcohol with quaternary ammonium groups column (Metrosep A Supp 5-150x4.0 mm); a solution of Sodium Carbonate $\left(3.2 \mathrm{mmol} \mathrm{L}^{-1}\right)$ and Sodium Bicarbonate $\left(1.0 \mathrm{mmol} \mathrm{L}^{-1}\right.$ in $5 \%$ acetone) was used as anion carrier and a solution of Tartaric Acid (4 mmol L-1) and Dipicolinic Acid $\left(0.75 \mathrm{mmol} \mathrm{L}^{-1}\right)$ was used as cation carrier. A HI 9828 multiparameter probe (Hanna) was used to monitor reactor DO, ORP, temperature and $\mathrm{pH}$.

A technique similar to the one applied by Brotto et al. (2015) was used for the emitted $\mathrm{N}_{2} \mathrm{O}$ sampling. Emitted $\mathrm{N}_{2} \mathrm{O}$ was collected using a modified lab-scale upturned funnel partially submerged in the reactor and a syringe (Figure 1A). The $\mathrm{N}_{2} \mathrm{O}$ flux (F) was calculated using Equation 1:

$$
F=\frac{Q \text { upturned funnel } x \Delta\left[N_{2} O\right]}{A_{\text {upturned funnel }}}
$$

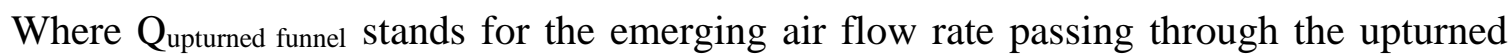
funnel, $\Delta\left[\mathrm{N}_{2} \mathrm{O}\right]$ is the difference between the $\mathrm{N}_{2} \mathrm{O}$ concentration determined in the reactor and the concentration present in the atmosphere and $A_{\text {upturned funnel }}$ is the superficial area of the upturned funnel.

Dissolved $\mathrm{N}_{2} \mathrm{O}$ was collected from the mixed liquor using a syringe and the concentration in the liquid was determined by the headspace gas method (de Mello et al., 2013). Dissolved $\mathrm{N}_{2} \mathrm{O}$ concentrations (C) were calculated with Equation 2:

$$
\mathrm{C}=\mathrm{K}_{0} \times \mathrm{C}_{\mathrm{hs}}+\left[\left(\frac{\mathrm{P}}{\mathrm{R} \times \mathrm{T}}\right) \times\left(\mathrm{C}_{\mathrm{hs}}-\mathrm{C}_{\mathrm{ar}}\right)\right]
$$

Where $\mathrm{K}_{0}$ is the $\mathrm{N}_{2} \mathrm{O}$ solubility coefficient (Weiss and Price, 1980), $\mathrm{C}_{\mathrm{hs}}$ is the $\mathrm{N}_{2} \mathrm{O}$ concentration stripped from the liquid (final), $\mathrm{P}$ is the atmospheric pressure, $\mathrm{R}$ is the universal gas constant, $\mathrm{T}$ is the liquid temperature $(\mathrm{K})$ and $\mathrm{C}_{\mathrm{ar}}$ is the $\mathrm{N}_{2} \mathrm{O}$ concentration present in the atmosphere (initial).

Both emitted and dissolved $\mathrm{N}_{2} \mathrm{O}$ were stored in glass vials containing a saturated saline solution following Bastviken et al. (2010). The $\mathrm{N}_{2} \mathrm{O}$ in the vial was recovered and analyzed on 
a GC-2014 gas chromatograph with flame ionization (FID) and electron capture detector (GCECD) (Shimadzu), using a Porapak-Q packed column, ultrapure $\mathrm{N}_{2}(99,999 \%)$ as carrier gas and argon containing 5\% $\mathrm{CH}_{4}$ as make-up.

\section{RESULTS AND DISCUSSION}

The SBR reached average COD, DOC and TN removal efficiencies of 89, 91 and 79\%, respectively, similar to those reported by other authors (Jia, et al., 2012; Rodriguez-Caballero et al., 2015). Jia et al. (2012) reported removal efficiencies of 91 and 85\% for COD and TN, respectively, in an anaerobic/aerobic SBR designed for simultaneous nitrification and denitrification (SND), with a 6-hour cycle. Rodriguez-Caballero et al. (2015) also reported removal efficiencies near $90 \%$, for both COD and TN in a full-scale SBR operated with alternate aerobic and anoxic phases in 4.5-hour cycles.

Despite the high TN removal obtained during this study, a high concentration of $\mathrm{NO}_{2}{ }^{-}$at the end of both the aerobic and anoxic phases was noted, with higher values in the aerobic phases (Figure 2). Too low $\mathrm{NO}_{3}{ }^{-}$concentrations $\left(<0.16 \mathrm{mg} \mathrm{N} \mathrm{L}^{-1}\right)$ during the cycle were also observed. These results can be an indicator that both nitrification and denitrification were only partial, as reported by other authors (Guo et al., 2009; Stenström et al., 2014; Du et al., 2016). Stenström et al. (2014) also observed $\mathrm{NO}_{2}^{-}$build-up in a SBR applying both nitrification and denitrification, indicating higher $\mathrm{NO}_{2}^{-}$production during nitrification and consumption reduction during denitrification throughout the study. Guo et al. (2009) observed $\mathrm{NO}_{2}{ }^{-}$ concentrations over $25 \mathrm{mg} \mathrm{N} \mathrm{L}^{-1}$ and $\mathrm{NO}_{3}{ }^{-}$concentrations under $6 \mathrm{mg} \mathrm{N} \mathrm{L}^{-1}$ in an SBR aerobic designed for partial nitrification. In the present study, the $\mathrm{NO}_{2}{ }^{-}$accumulation rate reached $96 \%$. Du et al. (2016), for an anoxic SBR designed for partial denitrification, reported that $\mathrm{NO}_{2}{ }^{-}$ accumulated due to decreased $\mathrm{NO}_{2}{ }^{-}$enzyme reduction activity. It is known that high nitritation rates may result in decrease of $\mathrm{pH}$, provoking a reaction shift of nitrite and nitrous acid upon $\mathrm{pH}$ below 5, which may impact the denitrification (Todt and Dörsch, 2016). However, the $\mathrm{pH}$ values measured in the present study were above 5 , which may not have been sufficient to increase nitrous acid production. This reinforces the theory that partial nitrification was responsible for the accumulation of nitrite.

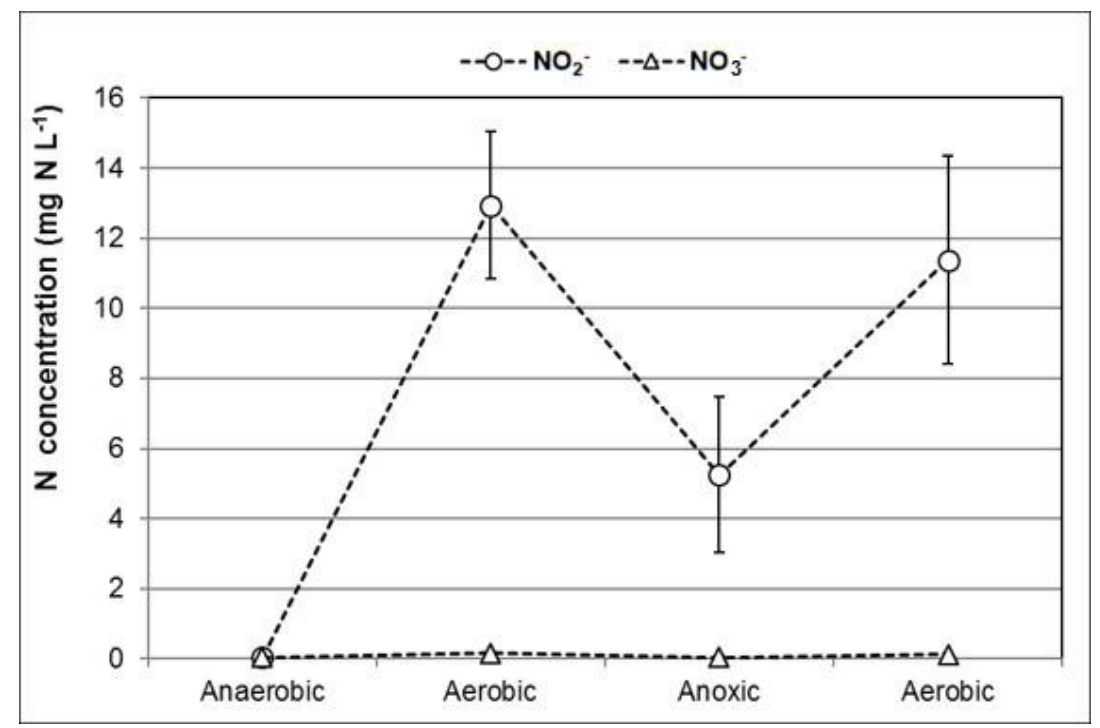

Figure 2. Mean $\mathrm{NO}_{2}^{-}$and $\mathrm{NO}_{3}{ }^{-}$concentrations $\left(\mathrm{mg} \mathrm{N} \mathrm{L}{ }^{-1}\right)$ and their respective standard deviations at the end of each metabolic phase.

Figure $3 \mathrm{~A}$ presents $\mathrm{NO}_{2}{ }^{-}$production (first aerobic phase), consumption (anoxic phase) and build-up (operational cycle) throughout the study. During the first aerobic phase, $\mathrm{NO}_{2}{ }^{-}$ 
consumption rates were high and varied from 43.1 to $63.8 \mathrm{mg} \mathrm{N} \mathrm{h}^{-1}$. In the next phase (anoxic), the consumption rates decreased throughout the sampling period, from 40.4 to $20.3 \mathrm{mg} \mathrm{N} \mathrm{h}^{-1}$. The combination of high partial nitrification rates $\left(\mathrm{NO}_{2}^{-}\right.$generation) during the first aerobic phase with decreased $\mathrm{NO}_{2}{ }^{-}$consumption in the subsequent anoxic phase led to $\mathrm{NO}_{2}{ }^{-}$build-up at the end of each operational cycle. The $\mathrm{NO}_{2}{ }^{-}$build-up rate increased from 29 to $57 \%$ at the end of each operational cycle and expresses the $\mathrm{NO}_{2}^{-}$percentage that was not consumed during the anoxic phase in relation to that produced in the previous phase (aerobic). Wu et al. (2011) observed $\mathrm{NO}_{2}{ }^{-}$accumulation rates near $90 \%$ in an anaerobic/aerobic SBR designed for partial nitrification with lower biomass concentrations, while Stenström et al. (2014) reported that $\mathrm{NO}_{2}{ }^{-}$accumulation can lead to increased $\mathrm{N}_{2} \mathrm{O}$ production and emission, as observed herein.

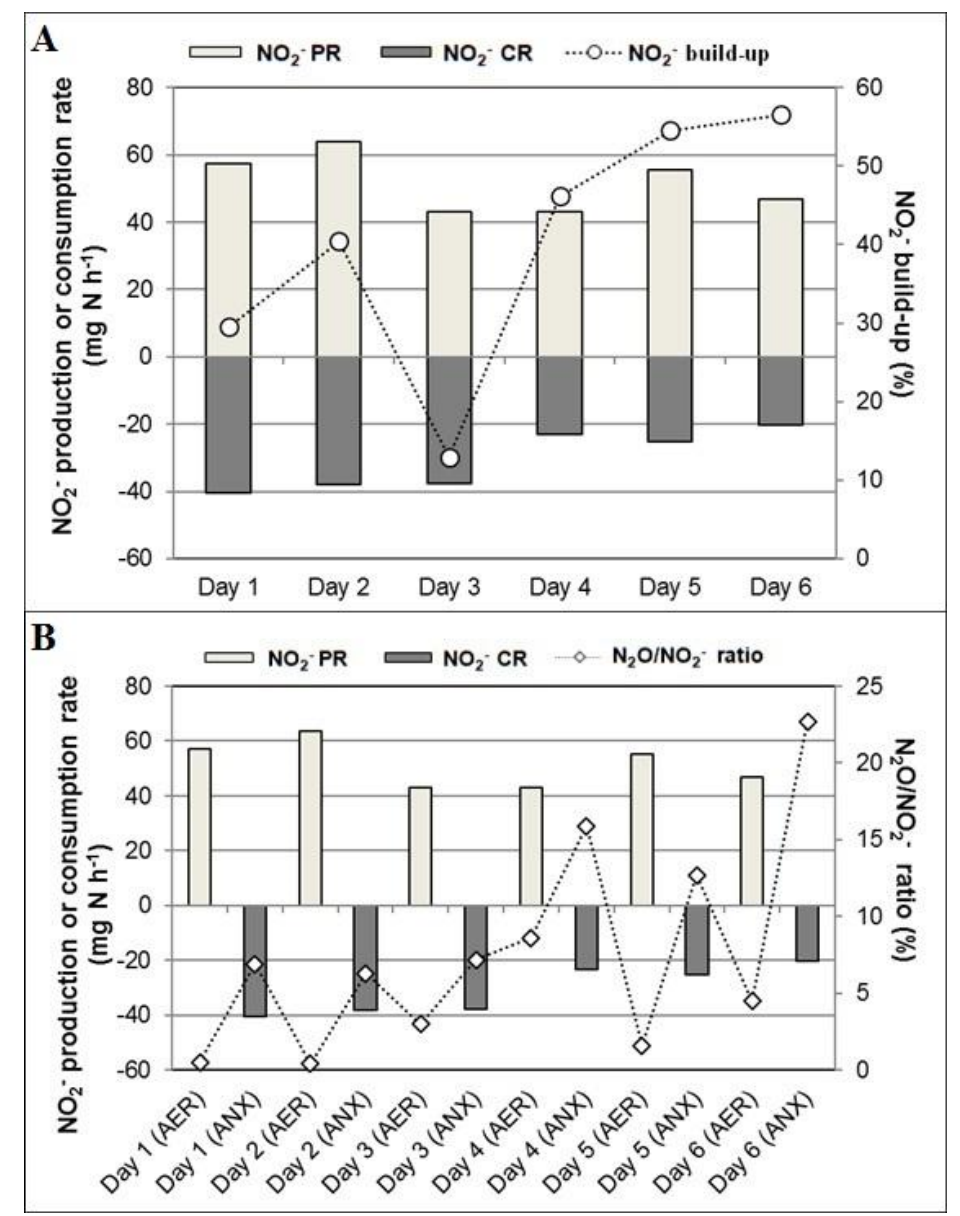

Figure 3. (A) $\mathrm{NO}_{2}^{-}$production $\left(\mathrm{mg} \mathrm{N} \mathrm{h}^{-1}\right)$ during the first aerobic phase, consumption ( $\left.\mathrm{mg} \mathrm{N} \mathrm{h}^{-1}\right)$ in the anoxic phase and build-up (\%) during the cycle. (B) $\mathrm{NO}_{2}^{-}$production (mg $\mathrm{N} \mathrm{h}^{-1}$ ) during the first aerobic phase, consumption $\left(\mathrm{mg} \mathrm{N} \mathrm{h}^{-1}\right)$ in the anoxic phase and the $\mathrm{N}_{2} \mathrm{O} / \mathrm{NO}_{2}^{-}$ratio (\%) of both phases.

Figure 3B indicates $\mathrm{NO}_{2}^{-}$production (first aerobic phase) and consumption (anoxic phase) rates and the $\mathrm{N}_{2} \mathrm{O} / \mathrm{NO}_{2}{ }^{-}$ratio for each phase (first aerobic and anoxic) during the study. The increased $\mathrm{NO}_{2}^{-}$build-up rate coincides with increased $\mathrm{N}_{2} \mathrm{O}$ production rate, raising the $\mathrm{N}_{2} \mathrm{O} / \mathrm{NO}_{2}{ }^{-}$ratio (Figure $3 \mathrm{~B}$ ). During the aerobic phase, $\mathrm{N}_{2} \mathrm{O}$ production accounted for 0.5 to $8.5 \%$ of $\mathrm{NO}_{2}{ }^{-}$production, where the main production mechanism was nitrification. During the anoxic phase, values were substantially higher and corresponded to the evolution of the denitrification process, ranging from 6.3 to $22.7 \%$. Therefore, denitrification was responsible 
for the higher $\mathrm{N}_{2} \mathrm{O}$ production in this type of system, being extremely important for the control of the operational conditions of the anoxic phase to mitigate $\mathrm{N}_{2} \mathrm{O}$ emissions in the following phases, mainly the aerobic stage. Rodriguez-Caballero et al. (2015) reported $\mathrm{NO}_{2}{ }^{-}$build-up as a key factor in increasing $\mathrm{N}_{2} \mathrm{O}$ production during nitrifying denitrification. Mampaey et al. (2016) described the anoxic phase as an important $\mathrm{N}_{2} \mathrm{O}$ generation factor, in addition to high $\mathrm{NO}_{2}{ }^{-}$concentrations. According to these authors, the anoxic phase was responsible for $70 \%$ of $\mathrm{N}_{2} \mathrm{O}$ production in a SHARON reactor. Therefore, effective operational parameter control, in order to minimize $\mathrm{NO}_{2}{ }^{-}$accumulation and, consequently, $\mathrm{N}_{2} \mathrm{O}$ supersaturation in the liquid, is necessary for $\mathrm{N}_{2} \mathrm{O}$ emission mitigation measures (Kampschreur et al., 2009; Vasilaki et al., 2019).

The higher $\mathrm{N}_{2} \mathrm{O}$ production rate occurring simultaneously with $\mathrm{NO}_{2}{ }^{-}$build-up in the system may be associated with a reduction in the reactor biomass (VSS). Figure 4 displays the $\mathrm{NO}_{2}{ }^{-}$ production (first aerobic phase) and consumption (anoxic phase) rates in parallel with the VSS concentrations in the reactor throughout the study period. A biomass concentration reduction of approximately $30 \%$ at the end of the sampling period was observed. The loss of biomass may be related to a mechanical problem in the mixer observed during the fifth week of sampling. The mixer malfunction led to sludge flotation during sedimentation, causing biomass losses through the treated wastewater discharge and, consequently, a sharp reduction in SRT. This event may have caused decreased efficiency of both the nitrification and denitrification processes, resulting in $\mathrm{N}_{2} \mathrm{O}$ and $\mathrm{NO}_{2}{ }^{-}$accumulation. $\mathrm{Wu}$ et al. (2011) observed that decreased suspended solid (SS) concentrations in an $\mathrm{SBR}$ system favored $\mathrm{NO}_{2}{ }^{-}$accumulation. Noda et al. (2003) reported higher concentrations of dissolved and emitted $\mathrm{N}_{2} \mathrm{O}$ in anoxic and oxide reactors with lower SRT. Other authors have also associated lower SRT with $\mathrm{NO}_{2}{ }^{-}$build-up and increased $\mathrm{N}_{2} \mathrm{O}$ production and emissions (Hanaki et al., 1992; Kampschreur et al., 2009; Castellano-Hinojosa et al., 2018).

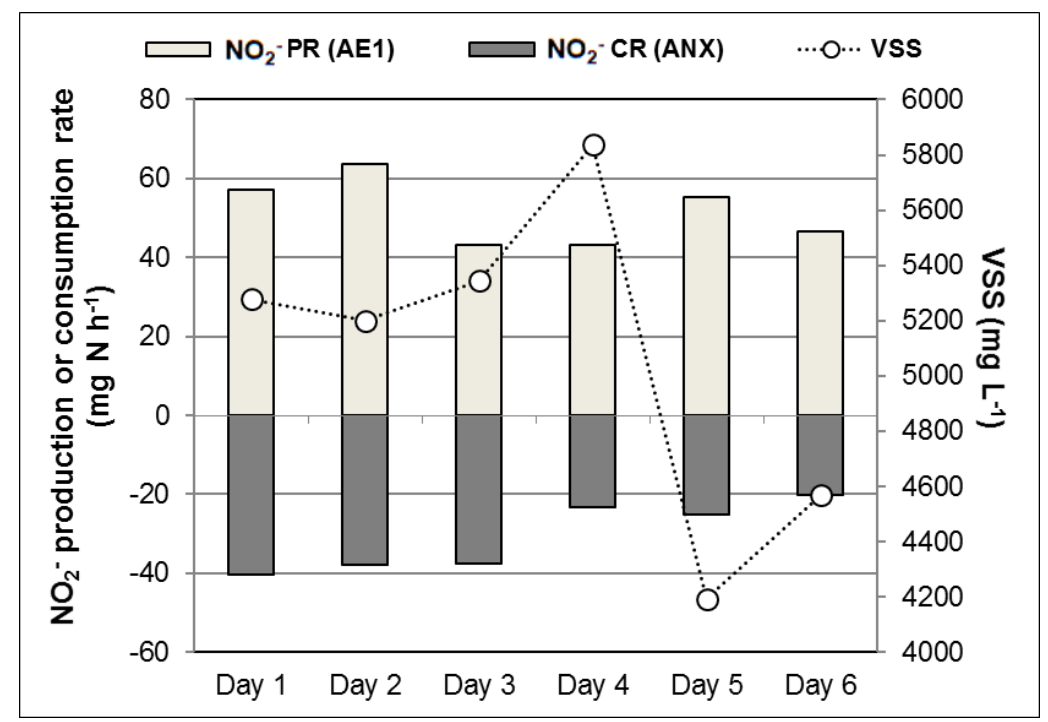

Figure 4. $\mathrm{NO}_{2}^{-}$production $\left(\mathrm{mg} \mathrm{N} \mathrm{h}^{-1}\right)$ during the first aerobic phase, consumption (mg $\mathrm{N} \mathrm{h}^{-1}$ ) in the anoxic phase and biomass concentrations (expressed as VSS $\mathrm{mg} \mathrm{N} \mathrm{L}^{-1}$ ).

As previously reported, solid losses in SBR alongside decreased SRT are likely to favor increasing $\mathrm{NO}_{2}^{-}$build-up and $\mathrm{N}_{2} \mathrm{O}$ generation. However, an additional effect was observed regarding the magnitude of the $\mathrm{N}_{2} \mathrm{O}$ transfer rate from the liquid to the atmosphere during the second aerobic phase. Figure 5 presents the $\mathrm{N}_{2} \mathrm{O}$ production rates (from the retained and notemitted portion) of the first aerobic and anoxic phases in parallel to the maximum $\mathrm{N}_{2} \mathrm{O}$ flux at the beginning of the second aerobic phase throughout the study period. The $\mathrm{N}_{2} \mathrm{O}$ flux peak 
occurred as soon as aeration began during the second aerobic phase, with substantially high values ranging from 706 to $2416 \mathrm{mg} \mathrm{N} \mathrm{m}^{-2} \mathrm{~h}^{-1}$. These findings are close to those reported by Ribeiro et al. (2017) in a conventional activated sludge WWTP with landfill leachate addition, where a maximum $\mathrm{N}_{2} \mathrm{O}$ flux of $1890 \mathrm{mg} \mathrm{N} \mathrm{m}^{-2} \mathrm{~h}^{-1}$ was observed, which was correlated to decreased DO concentrations and partial nitrification.

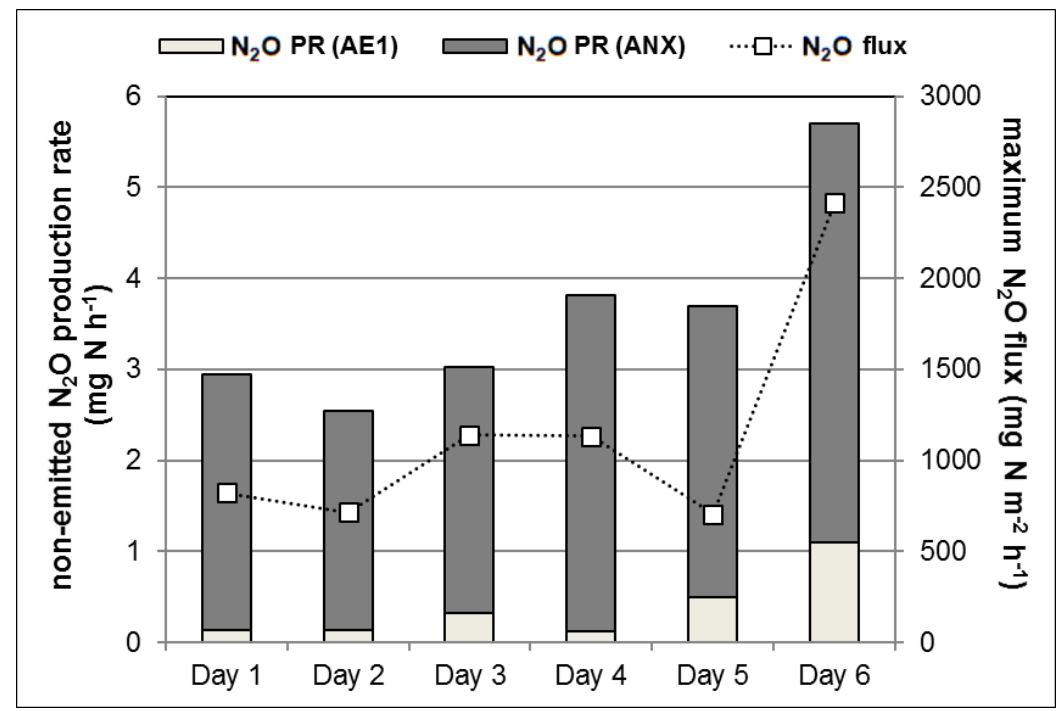

Figure 5. Non-emitted $\mathrm{N}_{2} \mathrm{O}$ production rate $\left(\mathrm{mg} \mathrm{N} \mathrm{h}^{-1}\right)$ during the first aerobic and anoxic phases and maximum flux emitted during the second aerobic phase $\left(\mathrm{mg} \mathrm{N} \mathrm{m}^{-2} \mathrm{~h}^{-1}\right)$.

In the present study, the peaks from the second aerobic phase represented the amount of $\mathrm{N}_{2} \mathrm{O}$ produced and retained (not emitted) from the previous phases (first aerobic and anoxic). The same behavior for $\mathrm{N}_{2} \mathrm{O} / \mathrm{NO}_{2}{ }^{-}$accumulation in the liquid phase was observed for the maximum $\mathrm{N}_{2} \mathrm{O}$ flux throughout the study period, with an increase in emitted $\mathrm{N}_{2} \mathrm{O}$ in parallel with an increased $\mathrm{N}_{2} \mathrm{O}$ production rate retained from the previous phases (Figure 5). Other studies have reported the same liquid $\mathrm{N}_{2} \mathrm{O}$ accumulation problem during the anoxic phase and its implications for the next aerobic phase (Gustavsson and La Cour Jansen, 2011; Yang et al., 2017; Pijuan et al., 2014; Mampaey et al., 2016). Thus, alternation between the anoxic and aerobic phases can be a negative point for $\mathrm{N}_{2} \mathrm{O}$ emission mitigation in wastewater treatment processes applying $\mathrm{N}$ removal.

Therefore, operational control in order to favor lower $\mathrm{N}_{2} \mathrm{O}$ production during the aerobic phase and its rapid consumption in the subsequent anoxic phase are necessary to mitigate emissions in the following phases, especially in the aerated units. Otherwise, in systems with a subsequent aerobic phase, $\mathrm{N}_{2} \mathrm{O}$ produced and not consumed may be emitted. In systems without this subsequent step, $\mathrm{N}_{2} \mathrm{O}$ may be emitted during treated wastewater disposal into receiving water bodies. Other operational adjustments, such as $\mathrm{NO}_{2}{ }^{-}$and SRT control, are extremely important to create favorable conditions for nitrification and denitrification processes without liquid $\mathrm{N}_{2} \mathrm{O}$ accumulation and subsequent emission.

\section{CONCLUSION}

This study correlates $\mathrm{N}_{2} \mathrm{O}$ production and emissions with the operational condition of an SBR undergoing anaerobic/aerobic/anoxic/aerobic phases. The main conclusions are:

- Even with controlled DO and ORP, partial nitrification was observed during the first 
aerobic phase, resulting in high $\mathrm{NO}_{2}^{-}$production. The $\mathrm{NO}_{2}^{-}$was not totally consumed during the anoxic phase, also indicating the partial denitrification.

- $\mathrm{NO}_{2}{ }^{-}$build-up favored $\mathrm{N}_{2} \mathrm{O}$ production during both the aerobic and anoxic phases of the process. The increases observed in both parameters can be associated with decreased biomass concentrations.

- The anoxic phase was responsible for the highest $\mathrm{N}_{2} \mathrm{O}$ production rates. The $\mathrm{N}_{2} \mathrm{O}$ accumulated during this phase was released during the second aerobic phase, causing emission peaks as soon as aeration began.

- An environment able to sustain complete nitrification and denitrification is required, minimizing $\mathrm{NO}_{2}{ }^{-}$accumulation and allowing for rapid $\mathrm{N}_{2} \mathrm{O}$ consumption, thus minimizing emissions.

\section{REFERENCES}

APHA; AWWA; WEF. Standard Methods for the examination of water and wastewater. 22nd ed. Washington, 2012. 1496 p.

BASTVIKEN, D.; SANTORO, A. L.; MAROTTA, H.; PINHO, L. Q.; CALHEIROS, D. F.; CRILL, P.; ENRICH-PRAST, A. Methane emission from Pantanal, South America, during low water season: toward more comprehensive sampling. Environmental Science and Technology, v. 44, p. 5450-5455, 2010. https://dx.doi.org/10.1021/es1005048

BROTTO, A.; KLIGERMAN, D.; ANDRADE, S.; RIBEIRO, R.; OLIVEIRA, J.; CHANDRAN, K.; MELLO, W. Factors controlling nitrous oxide emissions from a fullscale activated sludge system in the tropics. Environmental science and pollution

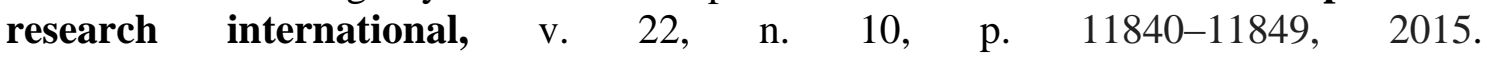
https://dx.doi.org/10.1007/s11356-015-4467-x

BLUM, J. M.; MARK, M. M.; SMETS, B. F. Nitrous oxide production in intermittently aerated Partial Nitritation-Anammox reactor: oxic N2O production dominates and relates with ammonia removal rate. Chemical Engineering Journal, v. 335, p. 458-466,2018. https://dx.doi.org/10.1016/j.cej.2017.10.146

CASTELLANO-HINOJOSA, A.; MAZA-MÁRQUEZ, P.; MELERO-RUBIO, Y.; GONZALEZ-LOPEZ, J.; RODELAS, B. Linking nitrous oxide emissions to population dynamics of nitrifying and denitrifying prokaryotes in four full-scale wastewater treatment plants. Chemosphere, v. 200, p. 57-66, 2018. https://dx.doi.org/10.1016/j.chemosphere.2018.02.102

DE MELLO, W. Z.; RIBEIRO, R. P.; BROTTO, A. C.; KLIGERMAN, D. C.; PICCOLI, A. S.; OLIVEIRA, J. L. M. Nitrous oxide emission from an intermittent aeration activated sludge system of an urban wastewater treatment plant. Química Nova, v. 36, p. 16-20, 2013. https://dx.doi.org/10.1590/S0100-40422013000100004

DU, R.; PENG, Y.; CAO, S.; LI, B.; WANG, S.; NIU, M. Mechanisms and microbial structure of partial denitrification with high nitrite accumulation. Applied microbiology and biotechnology, v. 100, p. 2011-2020, 2016. https://dx.doi.org/10.1007/s00253-0157052-9

DUAN, H.; YE, L.; ERLER, D.; NI, B. J.; YUAN, Z. Quantifying nitrous oxide production pathways in wastewater treatment systems using isotope technology - a critical review. $\begin{array}{llllll}\text { Water Research, } & \text { v. } & 122, & \text { p. }\end{array}$ https://dx.doi.org/10.1016/j.watres.2017.05.054 
FREITAS, A. M.; SIRTORI, C.; PERALTA-ZAMORA, P. G. Avaliação do potencial de processos oxidativos avançados para remediação de águas contaminadas com geosmina e 2-MIB. Química Nova, v. 31, n. 1, p. 75-78, 2008. https://dx.doi.org/10.1590/S010040422008000100016

GUO, J.; PENG, Y. Z.; WANG, S. Y.; ZHENG, Y. N.; HUANG, H. J.; GE, S. Effective and Robust Partial Nitrification to Nitrite by Real-Time Aeration Duration Control in an SBR Treating Domestic Wastewater. Process Biochemistry, v. 44 n. 9, p. 979-985, 2009. https://dx.doi.org/10.1016/j.procbio.2009.04.022

GUSTAVSSON D. J.; LA COUR JANSEN J. Dynamics of nitrogen oxides emission from a full-scale sludge liquor treatment plant with nitritation. Water science $\&$ technology, v. 63, n. 12, p. 2838-2845, 2011. https://dx.doi.org/10.2166/wst.2011.487

HANAKI, K.; HONG, Z.; MATSUO, T. Production of Nitrous Oxide Gas during Denitrification of Wastewater. Water science \& technology, v. 26, n. 5-6, p. 10271036,1992. https://dx.doi.org/10.2166/wst.1994.0260

HOLLER, S.; TRÖSCH, W. Treatment of urban wastewater in a membrane bioreactor at high organic loading rates. Journal of Biotechnology. v. 92, n. 2, p. 95-101, 2001. https://dx.doi.org/10.1016/S0168-1656(01)00351-0

IPCC. Climate Change 2014: Synthesis Report. Contribution of Working Groups I, II and III to the Fifth Assessment Report of the Intergovernmental Panel on Climate Change. Geneva, 2014.

IPCC. 2019 Refinement to the 2006 IPCC Guidelines for National Greenhouse Gas Inventories. Geneva, 2019.

JIA, W.; ZHANG, J.; XIE, H.; YAN, Y.; WANG, J.; ZHAO, Y.; XU, X. Effect of PHB and oxygen uptake rate on nitrous oxide emission during simultaneous nitrification denitrification process. Bioresource Technology, v. 113, p. 232-238, 2012. https://dx.doi.org/10.1016/j.biortech.2011.10.095

KAMPSCHREUR, M. J.; TEMMINK, H.; KLEEREBEZEM, R.; JETTEN, M. S. M.; VAN LOOSDRECHT, M. C. M. Nitrous oxide emission during wastewater treatment. Water Research, v. 43, p. 4093-4103, 2009. https://dx.doi.org/10.1016/j.watres.2009.03.001

LAW, Y.; YE, L.; PAN, Y.; YUAN, Z. Nitrous oxide emissions from wastewater treatment processes. Philosophical Transactions of the Royal Society B, v. 367, p. 1265-1277, 2012. https://dx.doi.org/10.1098/rstb.2011.0317

MAMPAEY, K. E.; DE KREUK, M. K.; VAN DONGEN, U. G. J. M.; VAN LOOSDRECHT, M. C. M.; VOLCKE, E. I. P. Identifying N2O formation and emissions from a full-scale partial nitritation reactor. Water Research, v. 88, p. 575-585, 2016. https://dx.doi.org/10.1016/j.watres.2015.10.047

NODA, N.; KANEKO, N.; MIKAMI, M.; KIMOCHI, Y.; TSUNEDA, S.; HIRATA, A.; MIZUOCHI, M.; INAMORI, Y. Effects of SRT and DO on N2O reductase activity in an anoxic-oxic activated sludge system. Water science \& technology, v. 48, n. 11-12, p. 363-370, 2003. https://dx.doi.org/10.2166/wst.2004.0881

PIJUAN, M.; TORÀ, J.; RODRÍGUEZ-CABALLERO, A.; CÉSAR, E.; CARRERA, J.; PÉREZ, J. Effect of process parameters and operational mode on nitrous oxide emissions from a nitritation reactor treating reject wastewater. Water Research, v. 49, p. 23-33, 2014. https://doi.org/10.1016/j.watres.2013.11.009 
RAVISHANKARA, A. R.; DANIEL, J. S.; PORTMAN, R. W. Nitrous oxide (N2O): the dominant ozone depleting substance emitted in the 21st century. Science, v. 326, p. $123-$ 125, 2009. https://dx.doi.org/10.1126/science.1176985

RIBEIRO, R. P.; BUENO R. F.; PIVELI, R. P.; KLIGERMAN, D. C.; DE MELLO, W. Z.; OLIVEIRA, J. L. M. The response of nitrous oxide emissions to different operating conditions in activated sludge wastewater treatment plants in Southeastern Brazil. Water Science \& Technology, v. 76, n. 9, p. $2337 \quad$ - 2349, 2017. https://dx.doi.org/10.2166/wst.2017.399

RODRIGUEZ-CABALLERO, A.; AYMERICH, I.; MARQUES, R.; POCH, M.; PIJUAN, M. Minimizing $\mathrm{N} 2 \mathrm{O}$ emissions and carbon footprint on a full-scale activated sludge sequencing batch reactor. Water Research, v. 71, p. 1 - 10, 2015. https://dx.doi.org/10.1016/j.watres.2014.12.032

STENSTRÖM F.; TJUS K.; LA COUR JANSEN J. Oxygen-induced dynamics of nitrous oxide in water and off-gas during the treatment of digester supernatant. Water Science \& Technology, v. 69, n. 1, p. 84-91, 2014. https://dx.doi.org/10.2166/wst.2013.558

TERADA, A.; SUGAWARA, S.; HOJO, K.; TAKEUCHI, Y.; RIYA, S.; HARPER, W. F.; YAMAMOTO, T.; KUROIWA, M.; ISOBE, K.; KATSUYAMA, C.; SUWA, Y.; KOBA, K.; HOSOMI, M. Hybrid Nitrous Oxide Production from a Partial Nitrifying Bioreactor: Hydroxylamine Interactions with Nitrite. Environmental Science \& Technology, v. 51, p. 2748-2756, 2017. https://dx.doi.org/10.1021/acs.est.6b05521

TODT, D.; DÖRSCH, P. Mechanism leading to N2O production in wastewater treating biofilm systems. Reviews in Environmental Science and Bio/Technology, v. 15, n. 3, p. 355378, 2016. https://dx.doi.org/10.1007/s11157-016-9401-2

VASILAKI, V.; MASSARA, T. M.; STANCHEV, P.; FATONE, F.; KATSOU, E. A decade of nitrous oxide (N2O) monitoring in full-scale wastewater treatment processes: A critical

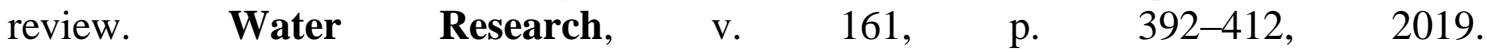
https://dx.doi.org/10.1016/j.watres.2019.04.022

VON SPERLING, M. Introdução à Qualidade das Águas e ao Tratamento de Esgotos. 3. ed. Belo Horizonte: UFMG, 2005.

YANG, Y.; TAO, X.; LIN, E.; HU, K. Enhanced nitrogen removal with spent mushroom compost in a sequencing batch reactor. Bioresource Technology, v. 244, n. 1, p. 897 904, 2017. https://dx.doi.org/10.1016/j.biortech.2017.08.050

WEISS, R. F.; PRICE, B. A. Nitrous oxide solubility in water and seawater. Marine Chemistry, v. 8, n. 4, p. 347-359, 1980. https://dx.doi.org/10.1016/0304-4203(80)900249

WRAGE, N.; VELTHOF, G. L.; VAN BEUSICHEM, M. L.; OENEMA, O. Role of nitrifier denitrification in the production of nitrous oxide. Soil Biology and Biochemistry, v. 33, p. 1723 - 1732, 2001. https://dx.doi.org/10.1016/S0038-0717(01)00096-7

WU, C.; PENG, Y.; WANG, S.; LI, X.; WANG, R. Effect of Sludge Retention Time on Nitrite Accumulation in Real-time Control Biological Nitrogen Removal Sequencing Batch Reactor. Chinese Journal of Chemical Engineering, v. 19. n. 3, p. 512-517, 2011. https://dx.doi.org/10.1016/S1004-9541(11)60014-1 